\title{
ANALISIS ORGANIZATION CITIZENSHIP BEHAVIOR (OCB) DAN DISIPLIN KERJA TERHADAP PRESTASI KERJA KARYAWAN
}

\author{
Hendra Hadiwijaya \\ Politeknik PalComTech \\ Jl. Basuki Rahmat No.05, Palembang 30129, Indonesia \\ Email: hendra_hadi@palcomtech.ac.id
}

\begin{abstract}
Abstrak - Analisis Organization Citizenship Behavior (OCB) dan Disiplin Kerja Terhadap Prestasi Kerja Karyawan. Sampel penelitian ini adalah pegawai di PT. Bank BPR Palembang yang berjumlah 48 orang dilakukan secara sensus. Penelitian ini bertujuan untuk mengetahui dan menganalisis besarnya pengaruh Organization Citizenship Behavior dan Disiplin Kerja terhadap Prestasi Kerja karyawan. Menggunakan Analisis regresi berganda dengan bantuan program SPSS (Statistical Package for Social Science). Hasil penelitian menunjukan Organization Citizenship Behavior dan Disiplin Kerja berpengaruh signifikan secara parsial dan simultan terhadap Prestasi Kerja pada Karyawan PT. Bank BPR Palembang. Disiplin Kerja berpengaruh dominan terhadap Prestasi Kerja Karyawan pada Karyawan PT. Bank BPR Palembang.
\end{abstract}

Kata kunci - Organization Citizenship Behavior, Disiplin Kerja, Prestasi Kerja Karyawan.

\section{Pendahuluan}

Organization Citizenship Behaviour menurut Luthans. F merupakan perilaku positif orang-orang yang ada dalam organisasi, yang terekspresikan dalam bentuk kesediaan secara sadar dan sukarela untuk bekerja, munculnya $O C B$ memberikan dampak positif tidak bagi dirinya juga membeikan kontribusi pada organisasi lebih daipada apa yang dituntut secara formal oleh organisasi. Individu yang memberi kontribusi pada keefektifan organisasi dengan melakukan hal di luar tugas atau peran utama mereka adalah asset bagi organisasi [1]. Manfaat Organization Citizenship Behavior terhadap organisasi adalah merurut Organ yaitu: 1). Meningkatkan produktivitas rekan kerja, 2).Meningkatkan produktivitas, 3). Menghemat sumber daya yang dimiliki manajemen dan organisasi secarakeseluruhan. 4). Menjadi sarana yang efektif untuk mengkoordinasi kegiatan tim kerja yangefektif. 5). Meningkatkan kemampuan organisasi untuk merekrut dan mempertahankankaryawan dengan kualitas performa yang baik. 6). Mempertahankan stabilitas Prestasi Kerja organisasi. 7). Membantu kemampuan organisasi untuk bertahan dan beradaptasi denganperubahan lingkungan. 8). Memiliki kemampuan untuk beradaptasi pada perubahan lingkungan. 9). Membuat organisasi lebih efektif dengan membuat modal sosial.[2].

Disiplin menurut Sondang P. Siagian adalah tindakan manajemen untuk mendorong para anggota organisasi memenuhi tuntutan berbagai ketentuan tersebut. Dengan perkataan lain, disiplin karyawan adalah salah satu bentuk pelatihan yang berusaha memperbaiki dan membentuk pengetahuan, sikap mental, kemampuan, dan perilaku karyawan sehingga para karyawan tersebut secara sukarela berusaha bekerja secara kooperatif dan dengan para karyawan yang lain serta meningkatkan prestasi kerjanya [3].Disiplin dalam suatu organisasi harus diwujudkan dalam bentuk peraturan yang memenuhi persyaratan sebagai berikut : a). Sedapat mungkin terperinci dan terpisah. b). Cukup singkat dan sederhana. c). Sedapat mungkin sederhana dan jelas, sehubungan dengan adanya sanksi atau hukuman. d). Fleksibel dan dinamis. [4].

Prestasi kerja karyawan dalam suatu organisasi yang dipengaruhi oleh tingkat kepuasan kerja, yaitu: Bahwa prestasi kerja diperusahaan dipengaruhi oleh tingkat kepuasan kerja. Produktivitas dan kepuasan kerja mempunyai hubungan positif atau searah, yaitu apabila kepuasan tinggi maka produktivitas juga akan tinggi, dan apabila kepuasan rendah maka produktivitas juga akan rendah.[5]. Prestasi kerja merupakan hasil kerja secara kualitas dan kuantitas, yang dicapai oleh seorang pegawai dalam melaksanakan tugasnya, sesuai dengan tanggung jawab yang diberikan kepadanya. Pengertian tersebut menunjukkan pada bobot kemampuan individu, untuk memenuhi ketentuan-ketentuan yang ada di dalam pekerjaannya. Prestasi kerja merupakan hasil upaya seseorang yang ditentukan oleh kemampuan, karakteristik pribadi serta persepsi terhadap peranannya dalam pekerjaan itu.[6].

Penelitian ini bertujuan untuk mengetahui dan menganalisis besarnya pengaruh Organization Citizenship Behavior dan Disiplin Kerja terhadap Prestasi Kerja karyawan PT. Bank BPR Palembang.

\section{KaJiAn LiterAtuR DAN PENGEMBANGAN HipoteSA}

A. Tinjauan Pustaka

1) Organization Citizenship Behavior (OCB)

Organization citizenship behaviour sebagai perilaku individu yang bersifat bebas (discretionary), yang tidak secara langsung dan eksplisit mendapat penghargaan dari sistem imbalan formal, dan yang secara keseluruhan (agregat) meningkatkan efisiensi dan efektifitas fungsi fungsi organisasi. Bersifat bebas dan suka rela, karena perilaku tersebut tidak diharuskan oleh persyaratan peran atau deskripsi jabatan yang secara jelas dituntut berdasarkan kontrak dengan organisasi, melainkan sebagai pilihan personal. [7] menguraikan definisi tersebut ke dalam beberapa poin sebagai berikut :

a) Perilaku individu yang bebas.

Maksudnya adalah perilaku tertentu yang dimunculkan dalam konteks tertentu bukan merupakan peryaratan 
mutlak yang tercantum dalam deskripsi pekerjaan yang harus dijalankan oleh seorang individu. Hal ini menyebabkan setiap individu memiliki pilihan secara bebas, apakah akan memunculjan $O C B$ atau tidak, karena akan dihukum karena tidak mempraktekkan perilaku tersebut.

b) Tidak secara langsung dan eksplisit diakui oleh system penghargaan formal.

Beberapa pekerjaan mencantumkan standar minimal seperti pengalaman, pengetahuan, dan kompetensi untuk memenuhi tanggung jawab pekerjaan secara tertulis.Ketika berbagai tuntutan tersebut dicantumkan dalam deskripsi pekerjaan, atau kontrak kerja, maka perilaku yang timbul dalam rangka memenuhi kewajiban tersebut bukanlah merupakan OCB.

c) Secara bersama-sama mendorong fungsi efisiensi dan efektifitas organisasi.

Pengertian secara bersama-sama di atas mengandung maksud bahwa OCB muncul pada setiap individu, pada kelompok, hingga pada tingkatan organisasi secara luas.

Organization citizenship behaviour (OCB) sebagai perilaku yang bersifat informal, melebihi harapan normal organisasi dan semuanya itu pada akhirnya dapat menjadikan kesejahteraan organisasi.OCB memiliki 5 (lima) dimensi [8] yang meliputi:

a) Altruism, merupakan perilaku menolong orang lain secara sukarela khususnya yang berhubungan dengan tugas di luar tanggung jawabnya dalam organisasi.

b) Courtesy, merupakan perilaku dimana karyawan bersikap sopan dan sesuai aturan, sehingga dapat mencegah timbulnya konflik interpersonal dalam organisasi.

c) Sportsmanship, merupakan perilaku yang menunjukkan daya toleransi yang tinggi terhadap organisasi sehingga seseorang akan berperilaku positif dan menghindari keluhan.

d) Conscientiousness, merupakan perilaku sukarela yang melebihi persyaratan dasar atau minimum pekerjaan dalam mematuhi aturan kerja maupun kehadirannya dalam organisasi.

e) Civic virtue, merupakan perilaku yang menunjukkan partisipasi dan kepedulian terhadap keberlangsungan hidup organisasi, seperti menghadiri rapat-rapat organisasi.

Mengetahui pentingnya $O C B$ para karyawan bagi kemajuan dan keberlangsungan perusahaan, maka $O C B$ perlu untuk dimunculkan dan ditingkatkan.Pemimpin organisasi harus memberikan contoh dan memperhatikan faktor-faktor yang mempengaruhi kemunculan OCB karyawan.Secara garis besar terdapat dua faktor yang berpengaruh terhadap tinggi rendahnya kemunculan $O C B$ para karyawan, yakni faktor dari dalam diri individu dan faktor dari luar diri individu. Hasil dari beberapa studi analisis mengidentifikasikan bahwa faktor dari luar yang berpengaruh terhadap $O C B$ diantaranya adalah kepuasan kerja, komitmen organisasi, maupun kepemimpinan

Manfaat Organization Citizenship Behavior menurut Organ [2] terhadap organisasi adalah:
1) Meningkatkan produktivitas rekan kerja

2) Meningkatkan produktivitas

3) Menghemat sumber daya yang dimiliki manajemen dan organisasi secarakeseluruhan.

4) Menjadi sarana yang efektif untuk mengkoordinasi kegiatan tim kerja yangefektif.

5) Meningkatkan kemampuan organisasi untuk merekrut dan mempertahankankaryawan dengan kualitas performa yang baik.

6) Mempertahankan stabilitas Prestasi Kerja organisasi.

7) Membantu kemampuan organisasi untuk bertahan dan beradaptasi denganperubahan lingkungan.

8) Memiliki kemampuan untuk beradaptasi pada perubahan lingkungan.

9) Membuat organisasi lebih efektif dengan membuat modal sosial.

\section{2) Disiplin Kerja}

Disiplin organisasi merupakan tindakan manajemen untuk mendorong para anggota organisasi memenuhi tuntutan berbagai ketentuan tersebut. Dengan perkataan lain, disiplin karyawan adalah salah satu bentuk pelatihan yang berusaha memperbaiki dan membentuk pengetahuan, sikap mental, kemampuan, dan perilaku karyawan sehingga para karyawan tersebut secara sukarela berusaha bekerja secara kooperatif dan dengan para karyawan yang lain serta meningkatkan prestasi kerjanya [9]. Disiplin dalam suatu organisasi harus diwujudkan dalam bentuk peraturan yang memenuhi persyaratan [4] sebagai berikut :

a. Sedapat mungkin terperinci dan terpisah.

b. Cukup singkat dan sederhana.

c. Sedapat mungkin sederhana dan jelas, sehubungan dengan adanya sanksi atau hukuman.

d. Fleksibel dan dinamis.

Dengan adanya peraturan yang jelas, tegas dan mudah dipahami secara benar oleh setiap anggota organisasi, maka yang perlu dikembangkan adalah bahwa sikap disiplin bukan saja merupakan tanggungjawab bawahan akan tetapi juga merupakan kewajiban seluruh para anggota organisasi atau perusahaan dari pimpinan sampai dengan para bawahan. Hanya dengan cara demikian disiplin akan berdampak positif bagi pencapaian tujuan perusahaan. Terdapat dua jenis disiplin dalam organisasi [9] yaitu :

a. Disiplin preventif : Adalah tindakan yang mendorong para karyawan, untuk taat kepada berbagai tentuan yang berlaku dan memenuhi standar yang telah ditetapkan. artinya melalui kejelasan dan penjelasan tentang pola sikap mental, tindakan, dan perilaku yang diinginkan dari setiap anggota organisasi dan diusahakan pencegahan jangan sampai para karyawan berperilaku negatif.

b. Disiplin Korektif: Merupakan suatu upaya menggerakkan karyawan dalam menyatukan suatu peraturan dan mengarahkan untuk tetap mematuhi peraturan sesuai dengan pedoman yang berlaku pada perusahaan. Pada disiplin korektif karyawan yang melanggar disiplin diberikan sanksi sesuai dengan ketentuan yang berlaku atau gagal memenuhi standar yang telah ditetapkan, dan kepadanya dikenakan sanksi disipliner. 


\section{3) Prestasi Kerja}

Prestasi kerja merupakan hasil kerja secara kualitas dan kuantitas, yang dicapai oleh seorang pegawai dalam melaksanakan tugasnya, sesuai dengan tanggung jawab yang diberikan kepadanya. Pengertian tersebut menunjukkan pada bobot kemampuan individu, untuk memenuhi ketentuanketentuan yang ada di dalam pekerjaannya. Prestasi kerja merupakan hasil upaya seseorang yang ditentukan oleh kemampuan, karakteristik pribadi serta persepsi terhadap peranannya dalam pekerjaan itu [6].

Faktor-faktor yang Mempengaruhi Prestasi Kerja Karyawan : Menurut Sutikno [10]:

"Tidak ada seorang pun yang dapat mencapai prestasi yang baik, tanpa kerja keras dan disiplin yang ketat. Prestasi kerja merupakan upaya individu/ pegawai, berdasarkan karakteristik dan kecakapan mental individu itu sendiri untuk mencapai; (1) hasil kerja secara kualitas; (2) kuantitas kerja dengan penuh tanggung jawab; (3) kemampuan mencapai target waktu maupun hasil yang diinginkan, bahkan melebihi dari target tersebut."

Menurut Dharma [11]:

"Ada banyak pengukuran yang dapat digunakan, seperti penghematan, tingkat kesalahan, dan sebagainya. Hampir seluruh cara pengukuran prestasi kerja mempertimbangkan aspek; (1) kuantitas; (2) kualitas; (3) ketepatan waktu

\section{Metode Penelitian}

\section{1) Sampel}

Sampel penelitian ini adalah pegawai di PT. Bank BPR Palembang yang berjumlah 48 orang dilakukan secara sensus, terdiri dari Pengurus ebanyak 4 orang, Kepala bagian sebanyak 1 orang, kepala seksi sebanyak 8 orang, staff sebanyak 29 orang, Security sebanyak 2 orang, Driver sebanyak 2 orang, Office boy sebanyak 2 orang.

\section{2) Metode Pengumpulan Data}

Metode yang dipergunakan untuk mengumpulkan data dalam penelitian ini adalah sebagai berikut :

1). Observasi: Pengumpulan data dengan cara mengadakan pengamatan langsung serta mencatat fenomena yang terjadi di lokasi penelitian.

2). Kuesioner: Pengumpulan data dengan menggunakan daftar pertanyaan yang disebarkan kepada responden di PT. Bank BPR Palembang . Daftar pertanyaan tersebut memuat indikator yang berkaitan dengan variabelvariabel Organization Citizenship Behavior dan Disiplin Kerja terhadap Prestasi Kerja Karyawan.

\section{3) Metode Analisis Data}

Metode analisis data akan digunakan teknik analisis Regresi Berganda yang tujuan untuk mengukur pengaruh satu atau beberapa variabel independen terhadap variabel dependennya. Alat bantu yang digunakan adalah software aplikasi statistik SPSS (Statistics for Product and Service Solution).

\section{4) Uji Instrumen}

A. Uji Validitas
Uji validitas menunjukkan seberapa cermat suatu alat tes melakukan fungsi ukurnya atau suatu alat ukur yang dapat mengukur apa yang ingin diukur. Dalam penelitian ini, alat ukurnya berupa kuesioner yang berisi pernyataanpernyataan yang mewakili Variabel bebas yakni Organization Citizenship Behavior dan Disiplin Kerja serta Variabel terikat yaitu Prestasi Kerja kayawan. Pengujian ini menggunakan program SPSS (Statistical Package for Social Science). Pengujian ini bertujuan untuk menguji apakah setiap item instrument (pernyataan) benar-benar mampu mengungkap faktor yang sudah diukur.Nilai validitas masing-masing pernyataan dapat dilihat dari nilai Corrected Item-Total Correlation masing-masing pernyataan. bila nilai Corrected Item-Total Correlation> 0,3 maka alat pengukur atau item pernyataan bersifat valid.[11].

B. Uji Reliabilitas

Uji Reliabilitas sebenarnya adalah alat untuk menilai konsistensi sebuah alat ukur atau kuesioner. Suatu kuesioner dikatakan reliable atau handal jika jawaban seseorang terhadap pertanyaan adalah konsisten atau stabil dari waktu kewaktu. Reliabilitas instrument diperlukan untuk mendapatkan data sesuai dengan tujuan pengukuran. Pada penelitian ini, pengujian reliabilitas diolah melalui SPSS versi 20. Uji reliabilitas dilakukan dengan menggunakan metode Cronbach's Alphadan diukur berdasarkan skala Cronbach's Alpha 0 sampai 1. Reliabilitas suatu konstruk variabel dikatakan baik jika memiliki nilai Cronbach's Alpha $>$ 0,60.[11]

\section{Uji Normalitas}

Kriteria dalam menguji normalitas sebagai berikut: a). Jika data menyebar garis diagonal dan mengikuti arah garis diagonal atau grafik histogram menunjukkan pola distribusi normal maka model regresi memenuhi asumsi Normalitas. b). Jika data menyebar garis diagonal dan tidak mengikuti arah garis diagonal atau grafik histogram, maka tidak menunjukkan pola distribusi normal maka model regresi tidak memenuhi asumsi Normalitas.[12]

\section{5) Analisis Regresi Berganda}

Analisis regresi berganda adalah suatu alat analisis peramalan nilai pengaruh dua atau lebih variabel bebas terhadap variabel terikat. Persamaan regresi berganda dirumuskan sebagai berikut:

$\mathrm{Y}=\mathrm{a}+\beta 1 \mathrm{X} 1+\beta 2 \mathrm{X} 2+\mathrm{e}$

Keterangan: Y : Prestasi Kerja karyawan, X1: Organization Citizenship Behavior, X2 : Disiplin Kerja, a: Intersep/konstanta, $\beta$ : koefisien regresi variable bebas, $e$ : Tingkat Kesalahan/error.

\section{6) Uji Hipotesis}

\section{A. Uji t ( Parsial)}

Secara parsial, pengujian hipotesis dilakukan dengan uji t-test. "uji statistik t pada dasarnya menunjukkan seberapa jauh pengaruh satu variabel penjelas/independen secara individual dalam menerangkan variabel dependen". Untuk menguji variabel yang berpengaruh antara X1, X2 terhadap Y secara individual (parsial) maka digunakan uji t. Adapun kriteria pengujian uji $\mathrm{t}$ adalah sebagai berikut : a). Jika $\alpha<$ 0,05 maka hipotesis diterima berarti ada pengaruh signifikan 
variabel independen (variabel bebas) secara parsial terhadap variabel dependen (variabel teikat). b). Jika $\alpha>0,05$ maka hipotesis ditolak berarti tidak ada pengaruh signifikan variabel independen (variabel bebas) secara parsial terhadap variabel dependen (variabel terikat).[12]

B. Uji F ( Simultan)

Secara simultan, pengujian hipotesis dilakukan dengan uji F-test. "uji statistik F pada dasarnya menunjukkan apakah semua variabel independen atau bebas yang dimasukkan dalam model mempunyai pengaruh secara bersama-sama terhadap variabel dependen/ terikat". Untuk menguji variabel yang berpengaruh antara X1, X2 terhadap Y secara bersamasama (simultan) maka digunakan uji F. [12] Adapun kriteria pengujian uji $\mathrm{F}$ adalah sebagai berikut : a). Jika Sig < 0,05 maka hipotesis diterima berarti ada pengaruh signifikan variabel independen secara simultan terhadap variabel dependen. b). Jika Sig > 0,05 maka hipotesis ditolak berarti tidak ada pengaruh signifikan variabel independen secara simultan terhadap variabel dependen.

\section{HASIL DAN PEMBAHASAN}

1) Uji Instrumen

a. Uji Validitas

Tabel 1

Pengujian Validitas Item Pernyataan Kuesioner

\begin{tabular}{|c|c|c|c|c|}
\hline & $\begin{array}{c}\text { Scale } \\
\text { Mean if } \\
\text { Item } \\
\text { Deleted }\end{array}$ & $\begin{array}{c}\text { Scale } \\
\text { Variance if } \\
\text { Item } \\
\text { Delete;d }\end{array}$ & $\begin{array}{c}\text { Corrected } \\
\text { Item-Total } \\
\text { Correlatio } \\
\text { n }\end{array}$ & $\begin{array}{l}\text { Cronbach's } \\
\text { Alpha if Item } \\
\text { Deleted }\end{array}$ \\
\hline X11 & 93,15 & 60,212 & ,585 & 938 \\
\hline X21 & 92,65 & 60,574 & 450 & 940, \\
\hline X31 & 93,44 & 56,762 & 749, & 935, \\
\hline X41 & 92,65 & 62,021 & 261 & 942 \\
\hline X51 & 93,52 & 58,085 & 785, & 935, \\
\hline X61 & 93,81 & 59,134 & 724 & 936 \\
\hline X71 & 93,56 & 58,890 & 670, & 937, \\
\hline X81 & 92,94 & 60,868 & 600 & 938, \\
\hline X12 & 92,69 & 57,113 & 934, & 933, \\
\hline X22 & 92,69 & 57,113 & 934, & 933, \\
\hline X32 & 93,77 & 61,968 & 329 & 949, \\
\hline X42 & 93,19 & 60,368 & 573, & 938, \\
\hline X52 & 92,94 & 54,570 & 635, & 940, \\
\hline X62 & 92,56 & 59,060 & 647, & 937, \\
\hline X72 & 92,94 & 60,868 & 600 & 938, \\
\hline X82 & 92,56 & 59,060 & 647, & 937, \\
\hline Y1 & 92,69 & 57,113 & 934, & 933, \\
\hline Y2 & 92,69 & 57,113 & 934, & 933, \\
\hline Y3 & 93,81 & 59,134 & 724 & 936 \\
\hline Y4 & 92,94 & 61,762 & 436 & 939, \\
\hline Y5 & 93,25 & 64,277 & 414 & 944, \\
\hline Y6 & 92,69 & 57,113 & 934 & 933, \\
\hline Y7 & 92,69 & 57,113 & 934, & 933, \\
\hline Y8 & 93,12 & 61,431 & 499 & 939 \\
\hline
\end{tabular}

Berdasarkan table 1 menunjukkan bahwa uji validalitas terhadap 48 responden dengan nilai Corrected Item-Total Correlation $>0,3$ pada seluruh butir pertanyaan (item) pada variabel Organization Citizenship Behavior dan Disiplin Kerja terhadap Prestasi Kerja Karyawan, sehingga data yang dihasilkan dapat dianalisis lebih lanjut. b. Uji Reliabilitas

Tabel 2. Pengujian Reliabilitas Item Pernyataan Kuesioner

\begin{tabular}{|c|c|c|c|c|}
\hline & $\begin{array}{c}\text { Scale } \\
\text { Mean if } \\
\text { Item } \\
\text { Deleted }\end{array}$ & $\begin{array}{c}\text { Scale } \\
\text { Varian } \\
\text { ce if } \\
\text { Item } \\
\text { Deleted }\end{array}$ & $\begin{array}{c}\text { Correcte } \\
\text { d Item- } \\
\text { Total } \\
\text { Correlati } \\
\text { on }\end{array}$ & $\begin{array}{l}\text { Cronbach' } \\
\text { s Alpha if } \\
\text { Item } \\
\text { Deleted }\end{array}$ \\
\hline $\begin{array}{l}\text { Organization } \\
\text { Citizenship } \\
\text { Behavior }\end{array}$ & 8,2656 & 485 & 915 & 944 \\
\hline Disiplin Kerja & 7,9688 & ,410 & 919 & 946 \\
\hline Prestasi Kerja & 8,0365 & 472 & 926 & 934 \\
\hline
\end{tabular}

Sumber: Hasil Olah Data Menggunakan SPSS

Berdasarkan table 2, menunjukkan bahwa uji reliabilitas dengan nilai Cronbach's Alpha $>0,60$ seluruh butir pertanyaan (item) pada semua variabel adalah reliable.

\section{2) Uji Normalitas}

Menurut Ghozali (2009) caranya normal probability plot yang membandingkan distribusi komulatif dari data sesungguhnya dengan distribusi komulatif dari distribusi normal. adapun kriteria sebagai berikut:

a) Jika data menyebar garis diagonal dan mengikuti arah garis diagonal atau grafik histogram menunjukkan pola distribusi normal maka model regresi memenuhi asumsi Normalitas.

b) Jika data menyebar garis diagonal dan tidak mengikuti arah garis diagonal atau grafik histogram, maka tidak menunjukkan pola distribusi normal maka model regresi tidak memenuhi asumsi Normalitas.

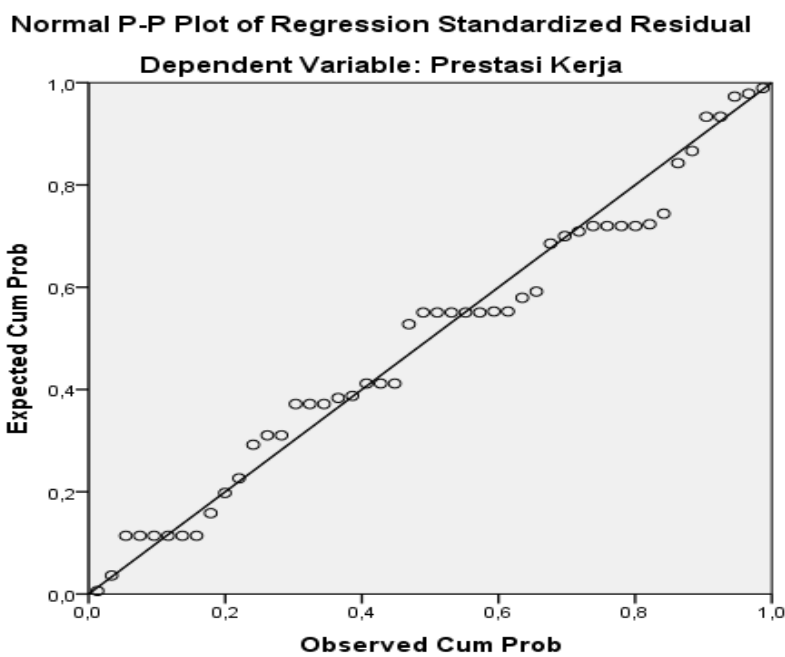

Gambar 1. Uji probability plot

Hasil kurva normal probability plot memperlihatkan bahwa titik-titik pada grapik berhimpit dan mengikuti gais diagonalnya, sehingga dapat disimpulkan model regresi berdistribusi normal.

\section{3) Analisis Regresi}

Analisis regresi dilakukan untuk mengetahui tingkat pengaruh antara variabel bebas terhadap variabel terikat baik secara simultan maupun parsial, juga untuk menguji hipotesis penelitian yang telah dirumuskan sebelumnya. Pada penelitian ini survei dilakukan terhadap 48 responden untuk 
melihat pengaruh Organization Citizenship Behavior dan Disiplin Kerja terhadap Prestasi Kerja Karyawan Pada PT. Bank BPR Palembang. Secara umum, deskriptif statistik untuk jawaban responden pada masing-masing variabel yang diteliti disajikan pada Tabel 3. di bawah ini:

Tabel 3. Descriptive Statistics

\begin{tabular}{|l|r|r|r|r|r|}
\hline & N & Min & Max & Mean & $\begin{array}{c}\text { Std. } \\
\text { Deviation }\end{array}$ \\
\hline $\begin{array}{l}\text { Organization } \\
\text { Citizenship } \\
\text { Behavior }\end{array}$ & 48 & 3,38 & 4,50 & $\begin{array}{r}3,869 \\
8\end{array}$ &, 32510 \\
Disiplin Kerja & 48 & 3,50 & 5,00 & $\begin{array}{r}4,166 \\
7\end{array}$ &, 38188 \\
$\begin{array}{l}\text { Prestasi Kerja } \\
\text { Valid N } \\
\text { (listwise) }\end{array}$ & 48 & 3,63 & 4,63 & 4,099 &, 33218 \\
\hline
\end{tabular}

Sumber : Data kuisioner yang diolah dengan SPSS, 2017

Organization Citizenship Behavior dan Disiplin Kerja terhadap Prestasi Kerja Karyawan Pada PT. Bank BPR Palembang . Data yang digunakan untuk analisis regresi dan uji hipotesis merupakan nilai rata-rata dari butir pertanyaan untuk setiap variabel, setelah data dikuantitatifkan dari data skala ordinal menjadi berskala ratio. Output koefisien regresi disajikan pada Tabel 4, di bawah ini:

Tabel 4 Hasil Analisa Regresi

Coefficients $^{\mathrm{a}}$

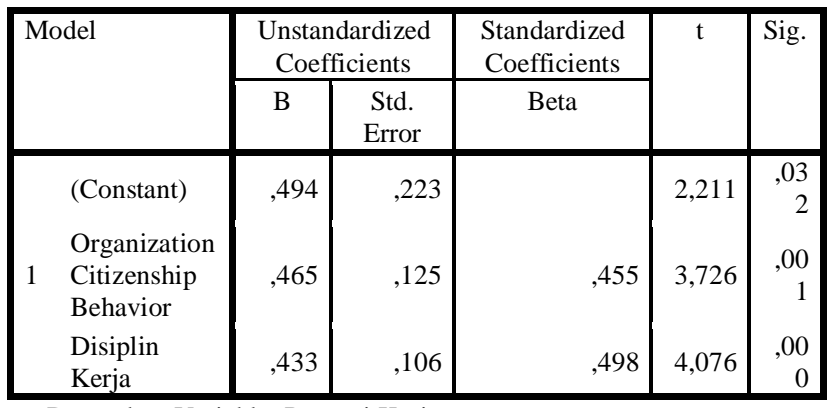

Sumber : Data kuisioner yang diolah dengan SPSS

Berdasarkan Tabel 4, maka persamaan regresi yang mencerminkan hubungan fungsional antara variabel terikat dengan variabel bebas adalah:

$$
\mathrm{Y}=0,494+0,465 \mathrm{X}_{1}+0,433 \mathrm{X}_{2}
$$

Besar nilai konstanta sebesar 0,494 pada persamaan regresi menunjukan bahwa nilai Y akan tetap sebesar 0,494 tanpa adanya pengaruh dari variabel-variabel bebas. Bila variabel $\mathrm{X}_{1}$ meningkat sebesar 1 satuan, maka nilai $\mathrm{Y}$ akan bertambah sebesar 0,465. Bila variabel $\mathrm{X}_{2}$ meningkat sebesar 1 satuan, maka nilai Y akan bertambah sebesar 0,433.

Berdasarkan persamaan garis regresi dugaan tersebut, maka:

- Koefisien regresi Organization Citizenship Behavior $\left(\mathrm{X}_{1}\right)$ bernilai positif sebesar 0,465, hal ini menunjukkan Organization Citizenship Behavior berpengaruh positif dan signifikan terhadap Prestasi Kerja (Y), sehingga Organization Citizenship Behavior akan berpengaruh terhadap Prestasi Karyawan PT. Bank BPR Palembang

- Koefisien regresi Disiplin Kerja $\left(\mathrm{X}_{2}\right)$ bernilai positif sebesar 0,433, hal ini menunjukkan Disiplin Kerja berpengaruh positif dan signifikan terhadap Prestasi Kerja (Y), sehingga Disiplin Kerja dapat meningkatkan Prestasi Kerja Karyawan PT. Bank BPR Palembang.

\section{4) Korelasi dan Koefisien Determinasi}

Korelasi menjelaskan hubungan antara variabel bebas $\left(\mathrm{X}_{1}\right.$,dan $\left.\mathrm{X}_{2}\right)$ yang tersusun dalam model persamaan regresi terhadap variabel Prestasi Kerja Karyawan PT. Bank BPR Palembang (Y). Sedangkan koefisien determinasi menjelaskan seberapa besar kontribusi yang diberikan oleh variabel bebas terhadap variabel Prestasi Kerja , berikut disajikan pada Tabel 5.

Tabel 5 Hasil Analisis Korelasi dan Koefisien Determinasi Model Summary

\begin{tabular}{l|c|c|c|c|}
\hline Model & $\mathrm{R}$ & $\mathrm{R}$ Square & $\begin{array}{c}\text { Adjusted R } \\
\text { Square }\end{array}$ & $\begin{array}{c}\text { Std. Error of } \\
\text { the Estimate }\end{array}$ \\
\hline 1 &, $926^{\mathrm{a}}$ &, 858 &, 852 &, 12788 \\
\hline
\end{tabular}
a. Predictors: (Constant), Disiplin Kerja, Organization Citizenship
Behavior
b. Dependent Variable: Prestasi Kerja
Sumber : Data kuisioner yang diolah dengan SPSS.

Berdasarkan Tabel 5, nilai $\mathrm{R}$ sebesar 0,926 dan mendekati angka 1 , dengan demikian berarti Organization Citizenship Behavior dan Disiplin Kerja mampu menjelaskan hampir semua variasi dari variabel Prestasi Kerja sehingga model regresi yang digunakan fit atau baik. Berdasarkan dari nilai Adjusted $R$ Square dapat diartikan pula Organization Citizenship Behavior dan Disiplin Kerja mampu mempengaruhi Prestasi Kerja Karyawan PT. Bank BPR Palembang sebesar 92,6\%.

\section{5) Uji Parsial}

Berikut ini adalah Tabel koefisien regresi yang digunakan sebagai dasar uji parsial.

Tabel 6 Coefficients

\begin{tabular}{|c|c|c|c|c|c|}
\hline \multirow[t]{2}{*}{ Model } & \multicolumn{2}{|c|}{$\begin{array}{l}\text { Unstandardize } \\
\text { d Coefficients }\end{array}$} & $\begin{array}{c}\text { Standardized } \\
\text { Coefficients }\end{array}$ & \multirow[t]{2}{*}{$\mathrm{t}$} & \multirow[t]{2}{*}{ Sig. } \\
\hline & B & $\begin{array}{l}\text { Std. } \\
\text { Error }\end{array}$ & Beta & & \\
\hline (Constant) & ,494 & ,223 & & 2,211 & ,032 \\
\hline $1 \quad \begin{array}{l}\text { Organization } \\
\text { Citizenship } \\
\text { Behavior }\end{array}$ & ,465 & 125 & 455 & 3,726 & ,001 \\
\hline $\begin{array}{l}\text { Disiplin } \\
\text { Kerja }\end{array}$ & ,433 & ,106 & 498 & 4,076 & ,000 \\
\hline
\end{tabular}

Sumber : Data kuisioner yang diolah dengan SPSS

$\mathrm{T}_{\text {table }}$ tergantung dari probabilitas $\alpha$ dan degree of freedom ( $d f$ ). Dimana jumlah $d f=$ jumlah sampel-jumlah variabel. Sehingga di peroleh $d f=48-3=45$ Dengan 
demikian, jika menggunakan $\alpha=5 \%$ maka di peroleh $\mathrm{t}_{\text {table }(\alpha, \mathrm{df})}$ $=\mathrm{t}_{(0.05,45)}=1.67943$

a) Uji Parsial (Uji t) untuk Variabel Organization Citizenship Behavior $\left(\mathrm{X}_{1}\right)$

Pengaruh $\mathrm{X}_{1}$ terhadap $\mathrm{Y}$, dapat diinterpretasikan berdasarkan uji probabilitas t-statistik Tabel 6, dengan $t_{\text {hitung }} 3,726>t_{\text {Tabel }} 1.67943 d a n$ sig. sebesar 0,001 lebih kecil dari 0.05, yang berarti variabel Organization Citizenship Behavior berpengaruh nyata terhadap variabel Prestasi Kerja. Hal ini berarti Organization Citizenship Behavior berpengaruh positif dan signifikan terhadap Prestasi Kerja Karyawan PT. Bank BPR Palembang .

Hasil pengujian dalam penelitian ini menyatakan Organization Citizenship Behavior berpengaruh positif terhadap Prestasi Kerja Karyawan PT. Bank BPR Palembang.

\section{b) Uji Parsial (Uji t) untuk Variabel Disiplin Kerja ( $\left.\mathrm{X}_{2}\right)$}

Pengaruh $\mathrm{X}_{2}$ terhadap $\mathrm{Y}$, dapat diinterpretasikan berdasarkan uji probabilitas t-statistik Tabel 6, dengan $t_{\text {hitung }}$ 4,076> $\mathrm{t}_{\text {Tabel }} 1.67943$ dan sig. sebesar 0,000 lebih kecil dari 0.05, yang berarti variabel Disiplin Kerja berpengaruh nyata terhadap variabel Prestasi Kerja. Hal ini berarti Disiplin Kerja berpengaruh positif dan signifikan terhadap Prestasi Kerja Karyawan PT. Bank BPR Palembang .

Hasil pengujian dalam penelitian ini yang menyatakan Disiplin Kerja secara parsial berpengaruh positif dan signifikan terhadap Prestasi Kerja Karyawan PT. Bank BPR Palembang.

6) Uji Hipotesis secara Simultan (Uji F) Pengaruh Variabel Bebas $\left(\mathrm{X}_{1}, \mathrm{X}_{2}\right)$ terhadap $\mathrm{Y}$

a). Uji hipotesis secara simultan dilakukan untuk menguji pengaruh variabel bebas secara bersama-sama terhadap variabel terikat Y. Dalam uji hipotesis secara simultan, digunakan uji F. Hasil pengujian simultan disajikan dalam Tabel 7 di bawah ini:

Tabel 7. ANOVA ${ }^{\mathrm{a}}$

\begin{tabular}{ll|r|r|r|c|c|}
\hline \multicolumn{1}{|l|}{ Model } & \multicolumn{1}{|c|}{$\begin{array}{c}\text { Sum of } \\
\text { Squares }\end{array}$} & df & $\begin{array}{c}\text { Mean } \\
\text { Square }\end{array}$ & F & Sig. \\
\hline & Regression & 4,450 & 2 & 2,225 & 136,069 &, $000^{\mathrm{b}}$ \\
1 & Residual &, 736 & 45 &, 016 & & \\
& Total & 5,186 & 47 & & & \\
\hline
\end{tabular}
a. Dependent Variable: Prestasi Kerja
b. Predictors: (Constant), Disiplin Kerja, Organization Citizenship
Behavior

Sumber : Data kuisioner yang diolah dengan SPSS.

Pada Tabel 7, merupakan Tabel sidik ragam (ANOVA). Tabel tersebut menjelaskan kelayakan model regresi untuk menjelaskan pengaruh variabel bebas $\mathrm{X}_{1}$, dan $\mathrm{X}_{2}$ terhadap variabel Y. Untuk menguji apakah model linier tersebut sudah tepat atau belum, maka $\mathrm{F}_{\text {hitung }}$ pada Tabel Anova perlu dibandingkan dengan $\mathrm{F}_{\text {Tabel. }}$

$F_{\text {table }}$ tergantung dari probabilitas $\alpha$ dan degree of freedom (df). Degree of freedom (df) untuk menentukan
$\mathrm{F}_{\text {Tabel }}$ ada dua yaitu $d f$ pembilang (N1) dan $d f$ penyebut (N2). Dimana $d f_{N 1}=$ Jumlah Variabel-1, sehingga di peroleh $d f_{N 1}=3-$ $1=2$, sedangkan $d f_{N 2}=$ jumlah sampel data-Jumlah variabel. Sehingga di peroleh $d f_{N 2}=48-3=45$ Dengan demikian, jika menggunakan $\alpha=5 \%$ maka diperoleh $\mathrm{F}_{\text {Tabel }(\mathrm{N} 1, \mathrm{~N} 2)}=\mathrm{F}(2,45)=$ 3.20 Berdasarkan uji $\mathrm{F}$ diperoleh nilai $\mathrm{F}_{\text {hitung }}(136,069)>$ $F_{\text {Tabel }}$ (3.20), untuk menguji signifikan diperoleh nilai sig ( $P$ value) $=0,000<0,05$, hal ini menunjukan pengaruh Organization Citizenship Behavior, Disiplin Kerja secara silmultan berpengaruh terhadap Prestasi Kerja Karyawan PT. Bank BPR Palembang.

$$
\text { V. Kesimpulan }
$$

Berdasarkan hasil analisis maka dapat di tarik beberapa simpulan sebagai berikut:

a) Organization Citizenship Behavior dan Disiplin Kerja berpengaruh signifikan secara parsial dan simultan terhadap Prestasi Kerja pada Karyawan PT. Bank BPR Palembang .

b) Disiplin Kerja berpengaruh dominan terhadap Prestasi Kerja Karyawan pada Karyawan PT. Bank BPR Palembang.

\section{SARAN}

Diharapkan untuk penelitian selanjutnya menambahkah variabel Lingkungan Kerja terhadap Prestasi Kerja serta variabel Motivasi kerja sebagai variabel intervening.

\section{UCAPAN TERIMAKASIH}

Penulis mengucapkan terima kasih kepada seluruh pihak yang telah memberi dukungan terhadap penelitian ini.

\section{REFERENSI}

[1] Hadiwijaya, Hendra. 2017. Analisis Organization Citizenship Behavior (OCB) dan Person Organization Fit (PO-Fit) terhadap Kinerja karyawan Bagian non medis Rumah Sakit Islam Siti Khodijah Palembang. Jurnal Motivasi. Vol.2 No. 1. Hal: 188-199.

[2] Organ, D.W., Podsakoff, Ph.M., Mackenzie, S.B. 2006 Organizational citizenship behaviour: its nature, antecedents, and consequences. Thousand OA: SAGE Publications.

[3] Hadiwijaya, Hendra dan Hanafi, Agustina. 2016. Pengaruh Kompetensi Dan Disiplin Terhadap Kepuasan Serta Implikasinya Pada Prestasi Kerja Karyawan. Jurnal Manajemen \& Bisnis Sriwijaya Vol. 14 No.3. Halaman: 407-418.

[4] Munandar. 2007. Manajemen Sumber Daya Manusia Perusahaan. Penerbit PT. Remaja Rosdakarya, Bandung.

[5] Robbins, Stephen P. dan Judge, Timothy A. 2008. Perilaku Organisasi, Buku 1 Edisi 12, Terjemahan. Jakarta: Salemba Empat.

[6] Mangkunegara, Anwar Prabu. 2009. Evaluasi Kinerja Sumber Daya Manusia. Bandung: Penerbit Refika Aditama.

[7] Organ, D. W., Pudsakoff, P. M., \& MacKenzie, S. B. 2006.Organizational Citizenship Behavior.Its Nature, Antecendents, and Consequences.California: Sage Publications, Inc.

[8] Greenberg, Jerald dan Baron, Robert A.. 2003. Behaviour in Organizations, Understanding and Managing The Human Side of Work. Third Edition.Allin and Bacon.A Division of Schuster.Massachuscets.

[9] Siagian, Sondang P. 2006. Manajemen Sumber Daya Manusia, Bumi Aksara, Jakarta.

[10] Luviansi, M., A. Djalil, dan R. Sambung. 2012. Analisis Pengaruh Motivasi Terhadap Prestasi Kerja Melalui Kepuasan dan Disiplin Kerja Pegawai. Jurnal Sains Manajemen 1(1) Halaman : 98-111. 
Seminar Nasional Teknologi Informasi, Bisnis, dan Desain 2017

STMIK - Politeknik PalComTech, 12 Juli 2017

[11] Wahid, Muhsin. 2010. Analisis Hubungan Kompetensi Karyawan Terhadap Prestasi Kerja pada BAAK, BAU dan Keuangan dalam Lingkup UMI. Economic Resources Journal 11(30) Halaman:101111.

[12] Ghozali, Imam. 2009. Aplikasi Analisis Multivariate dengan Program SPSS. Badan Penerbit Universitas Diponegoro. Semarang. 